\title{
MULTILINGUALISM OF A SOUTHERN ESTONIAN - COMPARISON OF ESTONIAN, VÕRU AND FINNISH NARRATIVES
}

\author{
Liina Tammmekänd
}

\begin{abstract}
The main subjects of the present case study are structural analysis of multilingual autobiographical narratives, and multilingualism and emotions. The respondent told an emotional story from her childhood in Estonian, in the Võru dialect and in Finnish. The author recorded, transcribed and analysed the three narratives keeping in mind four research questions: Do the narratives differ from each other structurally and thematically? Is the respondent's L1 emotionally closer to her? Does the respondent present different selves and emotional repertoire in her different languages? The narratives are structurally similar but thematically different. Because of the emotional vocabulary and themes in the Võru narrative, the Võru dialect seems emotionally closer to the respondent than the other two languages. No extensive conclusions could be made regarding the different selves. The speaker uses a different emotional repertoire in Finnish compared with the other languages. ${ }^{*}$
\end{abstract}

Keywords: multilingualism, oral narrative, emotion repertoire, Estonian, Võru dialect, Finnish

\section{Introduction}

The present article presents a case study on individual multilingualism in a Southern Estonian person. The author compared multilingual narratives on the same topic narrated by the respondent in Estonian, in the Vorru dialect and in Finnish. The following research questions were posed:

1. Do multilingual narratives differ structurally and thematically from each other?

2. Is the respondent's L1 emotionally closer to her than her other languages? (Cf. Bond, Lai 1986, Javier et al. 1993)

* This research was partly supported by ETF grant 9098 The Development of Dialogue Interpreting in Estonia: 
3. Does the respondent have different selves in her different languages? (Cf. Koven 1998)

4. Does the respondent have different emotional repertoires in her different languages? (Cf. Pavlenko 2002, Marian, Kaushanskaya 2008)

The article has five parts. After the introduction, the research method and the subject matter are introduced, followed by an overview of the respondent's language biography to give a context to the research. The main part of the article consists of the analysis and interpretation of the results, followed by the discussion and conclusion.

\section{Method and subject matter}

\subsection{Concepts and terms}

Researchers (Ervin-Tripp 1964, Javier et al. 1993, Anooshian, Hertel 1994, Pavlenko, Dewaele 2002, Dewaele 2004, Wierzbicka 2004) have described the emotional closeness of L1 thus: a multilingual might feel that her communication in L1 is emotionally more intense than her communication in L2. L2, however, could be used to distance oneself from emotions (Bond, Lai 1986, Dewaele 2004).

Jeanette Altarriba (2003) maintains that the seeming emotional closeness of L1 relates to the emotional vocabulary of L1 being stored at the deeper representational level of memory as it has been used in multiple contexts. Michael Bond and Tat Ming Lai (1986) think that the emotional closeness of L1 is connected to the language learning context. L1 is learned mainly at home which is a more emotional environment where certain words could be connected with anxiety during socialisation. L2 is learned at school which is an emotionally neutral environment where the vocabulary items might not form emotional connotations. However, not all studies give reason to claim that L1 is the emotional language of a person and L2 is not. For instance, there are cases where L1 cannot be determined because people have reached the level of a native speaker later in their life and attrition of L1 might have occurred (Piller 2002).

A distinction should be drawn between objectively measurable identity and subjectively describable self. In the case of multilinguals, in Estonian the term mitmikidentiteet (multiple identity) (Ehala 2004) is used, but in my view the term is more related to the cultural and socio-political side of society (e.g. an Estonian Russian, a speaker of the Võru dialect). Koven (1998) and Aneta Pavlenko (2006) use the term self to describe how a person feels when expressing herself in L2.

Some researchers (Koven 1998, Dewaele, Pavlenko 2001-2003, Marian, Kaushanskaya 2004, Pavlenko 2006) try to describe the selves of multilinguals claiming that multilinguals feel themselves as different persons when speaking different languages.

According to Pavlenko (2007, 2008), elicited fictional narratives and autobiographical narratives (Javier et al. 1993) are among of the most used ways of collecting data to study multilingualism. The autobiographical narrative can be divided into two sub-groups: the personal experience narrative and the language biography. Researchers have used language learners' diaries and language memoirs to study multilingualism (Verschik 2010). 


\subsection{Relevant research}

Susan Ervin-Tripp was one of the first researchers to use multilingual narratives to study multilingualism. Her research (1964) treated bilinguals who offered explanations to Thematic Apperception Test (TAT) pictures in their two languages. Ervin-Tripp found the L1 narratives more emotional and the narrative in L2 more abstract. The themes in the L1 and L2 narratives were different as well.

Rafael Javier, Felix Barrosi and Michele Muňos (1993) gave Spanish-English bilinguals five minutes to tell an emotional story from their past. The respondents chose the first session's language themselves. In the second session, the respondents told the same story in their other language. Between two sessions, there was a 20-minute interval. The researchers concentrated on the number of and elaboration on ideas expressed in the different languages. They found that the L1 narrative was richer in detail than the one in L2, which seemed to be more of a summary of the L1 narrative.

Michèle Koven (1998) studied personal experience narratives of two Portuguese-French bilinguals. There was no interval between the sessions. She analysed the narratives linguistically and had the respondents and their peers assess the narration. The linguistic analysis showed that the respondents used different lexical and morphosyntactic means and registers when speaking in L1 and L2. Both the respondents and their peers found that the respondents sounded like different persons in their different languages. Therefore, Koven concluded that multilingual people use different selves when speaking in their different languages.

In their research on emotional repertoires of multilinguals, Pavlenko and Viktoria Driagina (2007) found that multilinguals used different lexical and morphosyntactic devices for emotions in their different languages. Similar studies by Alexia Panayiotou (2004) and Viorica Marian and Margarita Kaushanskaya (2008) showed that a language might activate the socio-cultural framework connected to it so that a multilingual uses an appropriate emotional reaction in an appropriate context.

\subsection{The present case study}

In the present case study, the respondent told one emotional story about her childhood in three languages. There were long intervals (at least two weeks) between the sessions. All narratives were recorded and transcribed. The Võru, Estonian and Finnish narratives were 716, 610 and 434 words respectively. The narratives were analysed thematically and linguistically. The linguistic analysis concentrated on the use of deixis, grammatical tenses and emotion repertoires.

The use of deixis indicates how the narrator perceives her character and other characters in the narrative, how she positions the characters in relation to each other and how she conceives the narrated events. This implies emotional closeness of L1 and existence of different selves for different languages. The use of grammatical tenses indicates where the narrator places herself and the narratee and whether she uses emphatic narrative techniques. This implies again emotional closeness of L1. Differences in the use of emotion vocabulary and affective deixis signal the existence of different emotional repertoires that are at disposal of the narrator. From all the above thematic and structural differences arise in the three narratives. 
The respondent's language biography was also recorded to give the case study a more specific context. Language autobiographies are described by Pavlenko (2007) as life histories that 'focus on the languages of the speaker and discuss how and why these languages were acquired, used, or abandoned'. The respondent describes all learned languages, the time of study, the context and frequency of use and determines her passive and active skills in each language.

\section{Respondent's language biography}

The respondent, a 31-year-old woman with higher education, comes from Misso in Võrumaa. She is from a bilingual family where the parents spoke both standard Estonian and the Võru dialect to their children. The respondent acquired Estonian and the dialect simultaneously. She cannot remember whether her parents favoured standard Estonian or the dialect for different topics (e.g., family matters in the Vorru dialect and school problems in Estonian). The respondent communicated with her grandparents and other older people in the Võru dialect. Children in the village and at school spoke standard Estonian.

For the respondent, standard Estonian is the language of education and profession. She speaks the Võru dialect to these peers from her village who are not embarrassed by the fact that they know the dialect. She says that despite the fact that her father tries to speak standard Estonian with her when visiting, she feels a strong connection between her father and the dialect, which leads her to speak the dialect to her father. The respondent does not have a similar reaction to her mother. She uses a mix of standard Estonian and the dialect when speaking to her as the mother has been living with the respondent for six years in town.

In her second year at school (7-8 years), she started studying Russian. She watched soap operas on Russian TV and asked a classmate of Russian origin to speak Russian to her. The respondent cannot remember when she reached fluency in Russian, but she uses the language both in everyday and professional communication and in writing.

In the sixth year at school (12 years), a second foreign language was added to the curriculum. The respondent learned German according to the general curriculum until the last term of the last year at school. In the last term, she changed school and joined a class that learned German according to a special curriculum, which meant more German classes in a week. She had to work hard to catch up with her classmates who had been studying according to the German special curriculum for some years already. However, she scored well in the national examination of German and was accepted at university where she continued her German studies. During her BA studies she received a month-long grant to study German in Germany. The respondent uses German professionally and in writing.

The respondent also communicates in Finnish. She achieved fluency during actual communication in the professional context. She says that the Vorru dialect and Finnish are very similar for her and reaching fluency at the communicational level posed no problems. She recalls that at first she understood only $30 \%$ of what was spoken in Finnish and had to guess the reminder from the context. She describes that she learned 'like a child' by mimicking and imitating. She has asked the meanings 
of words from native speakers and has sometimes written the vocabulary items down. Finns assess her speaking skills as very good.

In the first years at university, the respondent took an elementary English course (6o academic hours). She has not studied English in a formal context since and has instead practised the language through actual communication. She uses the language both in everyday and professional communication and in writing.

The respondent is able to understand the gist of a conversation in Italian and Spanish and she can express the most important ideas related to her work in these languages. She has also had some contacts with French, but she says that her skills in this language are insufficient. It can be presumed that her passive knowledge of Romance languages arises from the fact the respondent studied Latin intensively for two terms at university, where she studied also two terms of classical Greek and biblical Hebrew, some Modern Greek and Modern Hebrew, none of which she uses either actively or passively.

\section{Analysis and interpretation}

\subsection{The general description of the three narratives - thematic blocks, utterances and words}

Both the personal experience narrative and the language biography were used to collect data. The respondent was asked to tell an emotional story from her childhood. At first, the respondent told the story in Estonian, then, after two weeks, in the Võru dialect and finally, after four months, in Finnish. All three narratives were recorded and transcribed. The respondent recounts the events of one summer day when she herded cattle with her friend. To fight boredom, she decides to learn how to ride a cow. She is successful, but her friend gets jealous and drives the cows home from the pasture. The narratives have three main characters; the narrator, her girlfriend and the cow.

At first, the narratives were analysed thematically. The thematic blocks of all narratives were determined, named provisionally and juxtaposed to find unique details from each narrative. Later, the words and utterances in each thematic block of every narrative were counted to calculate the average length of an utterance in each language (see Table 1). The comparison of the number of unique details, words and utterances in the Estonian, Võru and Finnish narratives showed which narrative has more information and of what nature this information is. Also the use of tenses and Sg1 verb form was determined, helping to understand how the respondent perceives herself in the tree languages.

The Estonian and Võru narratives are structurally very similar. Both narratives have fourteen thematic blocks with almost identical content and succession. The blocks, however, differ thematically. The Finnish narrative has only eleven thematic blocks, but its structure is similar to the other two narratives. There are also thematical similarities to the other two narratives but with noticeable differences as the narrator combines three successive thematic blocks and loses two blocks present in the other narratives. She introduces two new thematic blocks. The structure of all narratives is presented in Table 1. 
Table 1. Overview of the narratives

\begin{tabular}{|c|c|c|c|}
\hline \multirow{2}{*}{$\begin{array}{l}\text { Provisional names given } \\
\text { to the thematic blocks }\end{array}$} & \multicolumn{3}{|c|}{ Number of utterances $(\mathrm{U})$ and words $(\mathrm{W})$; notes } \\
\hline & Estonian narrative & Võru narrative & Finnish narrative \\
\hline 1. Introduction & $\begin{array}{l}4 \mathrm{U}, 22 \mathrm{~W} \\
\text { unique detail }\end{array}$ & $2 \mathrm{U}, 5 \mathrm{SW}$ & $3 \mathrm{U}, 13 \mathrm{SW}$ \\
\hline 2. Working as a milk maid & $5 U, 38 W$ & $7 U, 42 W$ & \multirow{3}{*}{$\begin{array}{l}7 \mathrm{U}, 54 \mathrm{~W} \\
\text { three thematic blocks are } \\
\text { combined }\end{array}$} \\
\hline $\begin{array}{l}\text { 3. Hard work of a milk } \\
\text { maid }\end{array}$ & $3 U, 27 W$ & $4 U, 54 W$ & \\
\hline $\begin{array}{l}\text { 4. Easy work of a } \\
\text { shepherd }\end{array}$ & $3 \mathrm{U}, 28 \mathrm{~W}$ & $\begin{array}{l}5 \mathrm{U}, 47 \mathrm{~W} \\
\text { two unique details }\end{array}$ & \\
\hline 5. Tediousness & $3 \mathrm{U}, 33 \mathrm{~W}$ & $\begin{array}{l}7 \mathrm{U}, 60 \mathrm{~W} \\
\text { two unique details }\end{array}$ & \multirow{2}{*}{$\begin{array}{l}5 \mathrm{U}, 39 \mathrm{~W} \\
5 \mathrm{U}, 32 \mathrm{~W} \\
\text { two blocks with different } \\
\text { subject matter (Dream and } \\
\text { The Friend); two unique } \\
\text { details }\end{array}$} \\
\hline 6. Description of the cow & $\begin{array}{l}6 \mathrm{U}, 32 \mathrm{~W} \\
\text { unique detail }\end{array}$ & $1 \mathrm{U}, 8 \mathrm{~W}$ & \\
\hline 7. Teaching the cow & $11 \mathrm{U}, 74 \mathrm{~W}$ & $10 \mathrm{U}, 78 \mathrm{~W}$ & $5 U, 27 \mathrm{~W}$ \\
\hline 8. Riding the cow & $5 \mathrm{U}, 41 \mathrm{~W}$ & $5 U, 49 W$ & $7 \mathrm{U}, 49 \mathrm{~W}$ \\
\hline 9. Friend is jealous & $7 \mathrm{U}, 71 \mathrm{~W}$ & $7 \mathrm{U}, 60 \mathrm{~W}$ & $2 U, 17 W$ \\
\hline 10. Explanation-interlude & $7 \mathrm{U}, 73 \mathrm{~W}$ & $\begin{array}{l}6 \mathrm{LU}, 57 \mathrm{~W} \\
\text { unique detail }\end{array}$ & block is absent \\
\hline 11. Cows go home & $6 \mathrm{U}, 42 \mathrm{~W}$ & $5 U, 66 \mathrm{~W}$ & $7 U, 46 W$ \\
\hline 12. A quick ride & $2 U, 56 \mathrm{~W}$ & $\begin{array}{l}11 \mathrm{U}, 87 \mathrm{~W} \\
\text { unique detail }\end{array}$ & $2 U, 20 W$ \\
\hline 13. Unexpected twist & $6 \mathrm{U}, 31 \mathrm{~W}$ & $\begin{array}{l}\text { 6LU, 46W } \\
\text { unique detail }\end{array}$ & $2 \mathrm{U}, 14 \mathrm{~W}$ \\
\hline 14. Conclusion & $5 U, 42 w$ & $\begin{array}{l}7 \mathrm{U}, 59 \mathrm{~W} \\
\text { unique detail }\end{array}$ & $\begin{array}{l}20 \mathrm{U}, 116 \mathrm{~W} \\
\text { block with different } \\
\text { subject matter; unique } \\
\text { detail }\end{array}$ \\
\hline
\end{tabular}

There are 106, 71 and 67 utterances in the Võru, Estonian and Finnish narrative respectively (see Figures 1 and 2). The average length of the Estonian utterance is 8.6 words and that of the Võru utterance 6.8 words, which makes the average Võru utterance $21 \%$ shorter than the average Estonian utterance. The average length of the Finnish utterance (6.5 words) is rather similar to that of the average Võru utterance.

The Võru narrative has 35 utterances more than the Estonian narrative, which shows that the narrator makes more pauses in the Võru narrative and thus apparently structures the narrative better. The Võru introduction is laconic, but later the number of utterances increases and remains high through the whole Võru narrative. The Estonian narrative has more utterances than the Võru narrative only in the first and the last thematic block. Regarding the number of utterances, the Võru narrative has four peaks and the Estonian narrative has three peaks. Two of these peaks coincide (see Figure 1). The Finnish narrative has the peak in its last thematic block that corresponds to the last block if the Estonian and Võru narrative (see Figure 2). 


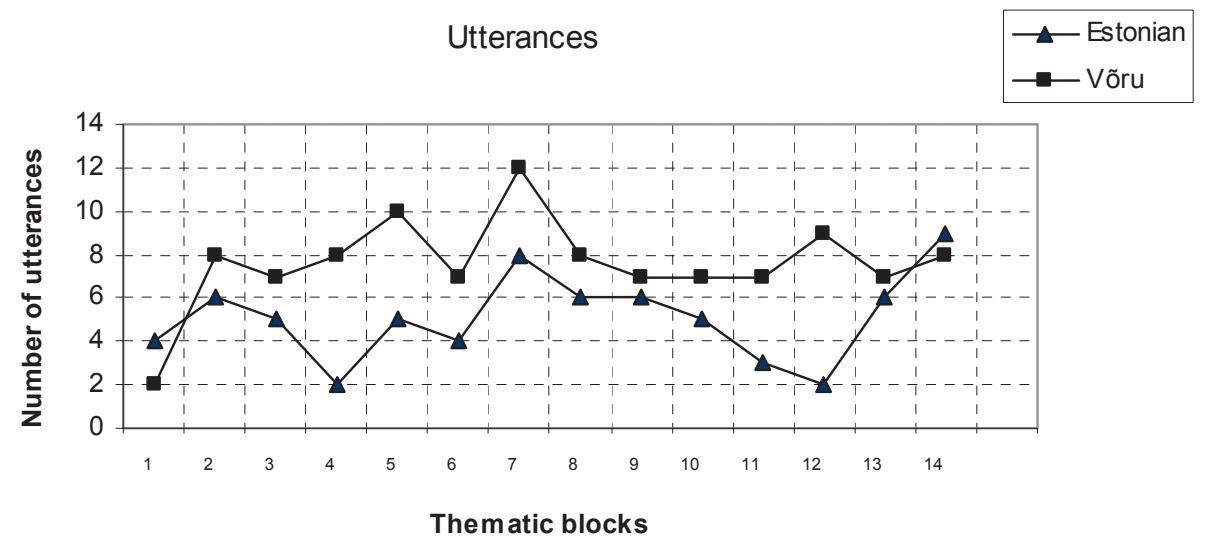

Figure 1. Number of utterances in thematic blocks in the Estonian and Võru narrative

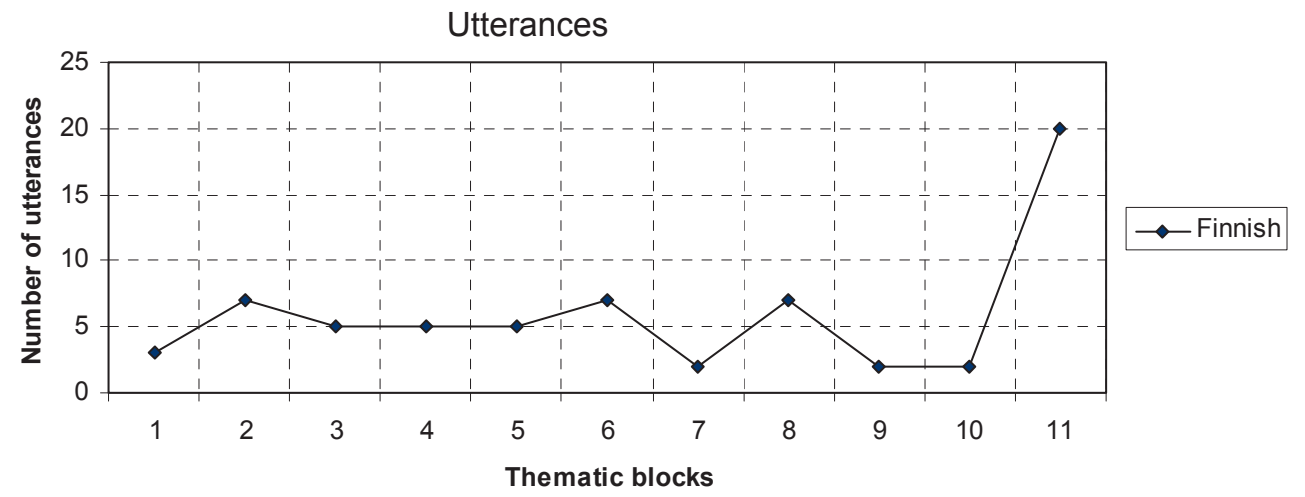

Figure 2. Number of utterances in thematic blocks in the Finnish narrative

The Võru narrative with its 716 words is the longest narrative. The Estonian narrative has 610 words and is $15 \%$ shorter than the Võru narrative. The Finnish narrative has 434 words and is $40 \%$ and $29 \%$ shorter than the Võru and Estonian narrative respectively (see Figures 3 and 4).

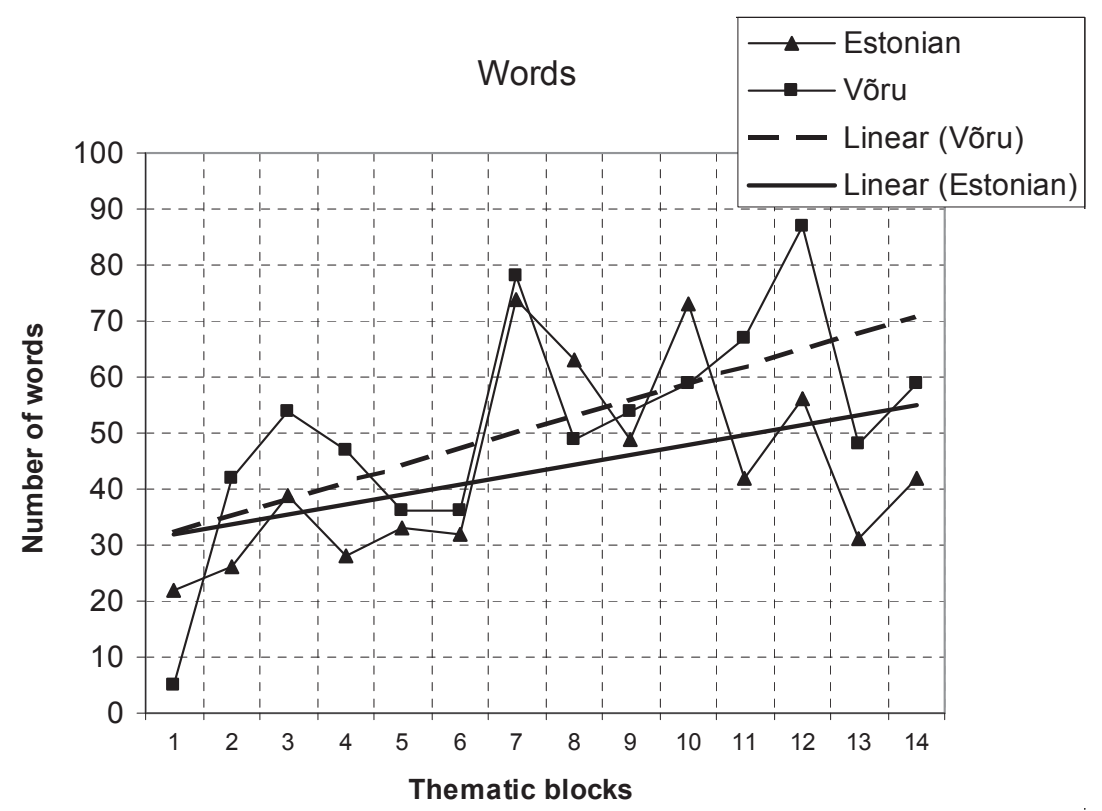

Figure 3. Number of words in thematic blocks in the Estonian and Võru narratives 


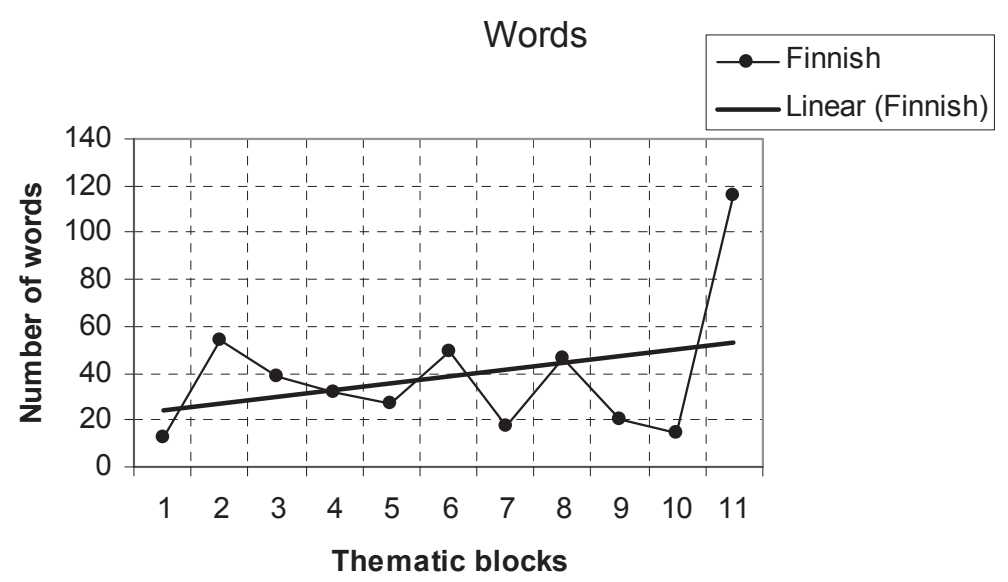

Figure 4. Number of words in thematic blocks in the Finnish narrative

Regarding the number of words, the Võru narrative has three peaks and the Estonian narrative has four peaks. One of these peaks coincides (see Figure 3). Some thematic blocks in the Finnish narrative have more words than others because the narrator integrates and adds thematic blocks. In the last block, she has introduced a new theme as well (see Figure 4).

All three narratives are structurally rather similar. However, in the Finnish narrative the narrator integrates, loses and adds thematic blocks, which makes the Finnish narrative three thematic blocks shorter than the other two narratives.

There is a $\mathbf{2 1 \%}$ difference in the length of the average utterance in the Vorru and Estonian narratives. Both in utterances and in words, the Võru narrative is the longest and the Finnish narrative is the shortest. It can be assumed that the longest narrative, the Võru narrative, has the highest number of details and the shortest narrative, the Finnish narrative, gives a clipped overview of the event. However, the shortness of the Finnish narrative might be because the narrator uses the language in her professional communication and she does not possess the necessary vocabulary.

\subsection{Use of tenses in the narratives}

Monika Fludernik (2003) mentions five tenses used in narratives: narrative past, epic preterite, narrative present, historical present and epic present. In the context of the current study, three tenses take on a specific importance. According to Fludernik, narrative past is the default tense in past narratives, specifying the time and place of the events of the narrative. Narrative present refers to the deictic centre of the narrator and the narratee and is the tense in which the narrator addresses the narratee and conveys universal truths. Historical present is used to highlight important places in the narrative. Other authors (Wolfson 1979, Schriffrin 1981) describe historical past also as a tense (1) that adds to the dramatic effect of the narrative so that the narratee feels like she herself has witnessed the events being narrated, or (2) as a tense that leaves the impression of the narrator being absorbed in the narrative that she seems to relive the events being narrated (discourse time and story time appear to coincide).

As the case study deals with a past narrative, the narrator should use mainly past tenses. This is true for the Estonian narrative as there are $72 \%$ more past tense verbs 
than present tense verbs ( 74 verbs in past; 21 verbs in present). Compared with the Estonian narrative, the narrator, however, uses present tense forms approximately $50 \%$ more in the Võru narrative (95 verbs in past; 41 verbs in present). Additionally, the narrator uses also perfect and past perfect in the Võru narrative, but she uses them both only once.

The narrator uses many present tense forms in the Finnish narrative: $63 \%$ of the verbs are in the present tense (22 verbs in past; 40 verbs in present). additionally, the narrator uses perfect tense once.

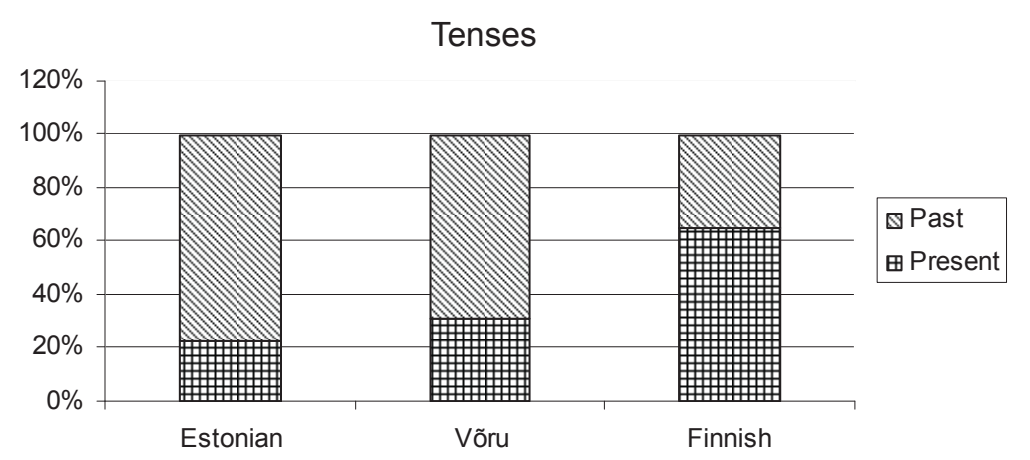

Figure 5. Use of tenses in the three narratives

In Estonian, the narrator uses predominantly the past tense, as if looking back to the event. It might be assumed that with such a choice, she distances herself from the event and acts as a bystander. In the Võru narrative, the narrator uses the present tense approximately 50\% more than in the Estonian narrative. The use of the past tenses is proportionally higher in the Vorru narrative, as the narrative itself is longer, but it can still be presumed that by the use of the present (historic present, in this case) the narrator has set herself in the middle of the event. She is not a neutral bystander, but rather a participant. The narrator has used also perfect and past perfect in the Võru narrative, which diversifies the use of tenses on a small scale but at the same time introduces a temporal dimension to the narrative. The narrator does not switch between past and present like she does in the Estonian narrative. however, any further conclusion about the use of perfect and past perfect cannot be drawn as these appear in the Võru narrative only once.

As the differences in the use of tenses in the Estonian and Võru narrative arise probably from the different thematical stresses (see subdivision 4.5), it can be presumed that the high use of the present in the Finnish narrative is rather the result of the narrator's low functionality in the language. It seems that the narrator finds it easier to form verbs in present. There is a noticeable influence of the Võru dialect on forming tenses in Finnish (for example kado vs. katson 'I look', hellitä vs. hellin 'I caress', es ole vs. ei ollut 'was not').

\subsection{Use of Sg1 verb form with and without a pronoun}

Lindström et al. (2009) conducted a study the aim of which was to determine whether the use of the pronoun 'I' is influenced by the verb ending in the Vorru dialect (the indicative affirmative verb in the first person singular is either marked or not). The study concludes that the use of Sg1 pronoun does not depend on the verb 
marking. It is also noted that the Sg1verb form is mostly used with the pronoun in the Võru dialect. The table below, however, demonstrates that in the present case study the narrator uses the pronoun especially extensively.

Table 2. Use of Sg1 verb form with and without a pronoun

\begin{tabular}{|l|c|c|c|c|}
\hline \multicolumn{1}{|c|}{ Study } & Sg1 with a pronoun & In all: & Sg1 without a pronoun & In all: \\
\hline Lindström et al. (2009) & $63.1 \%$ & 195 & $36.9 \%$ & 48 \\
\cline { 1 - 1 } Here (in the Võru dialect) & $89.5 \%$ & 43 & $10.5 \%$ & 5 \\
\hline
\end{tabular}

Similarly, the narrator prefers to use $S g 1$ verb form with a pronoun than without it in the Estonian and Finnish narratives also. At first glance it seems that the narrative is very 'self-centred' in all languages. Below, the structure of the narrative and themes in different languages are described and it can be seen that the narrator actually shifts focalisation away from herself from time to time in all languages. At the moment, it has to be presumed that the extensive use of a pronoun with Sg1 verb form in the Võru dialect is a characteristic trait of the narrator or the sign of the language change.

To sum up, the respondent uses Sg1 pronouns extensively in all three narratives.

\subsection{Deictic relations}

The narrator uses almost the same number of different deictics in the Estonian and Võru narratives ( 59 and 57 deictics in the Estonian and Võru narrative respectively). In the Finnish narrative, the narrator uses 32 different deictics. Table 3 gives an overview of the use of deictics in the three languages.

Table 3. Overview of deictics in the three narratives

\begin{tabular}{|l|c|c|c|c|}
\hline \multicolumn{2}{|c|}{ Category of deixis } & Estonian & Võru dialect & Finnish \\
\hline \multicolumn{2}{|c|}{ Place (demonstrative) } & 32 & 46 & 18 \\
\hline \multirow{4}{*}{ Person } & $1 \mathrm{Sg}$ & 48 & 51 & 25 \\
\cline { 2 - 5 } & $2 \mathrm{Sg}$ & 2 (addressing the listener) & 2 (generic "you") & 4 (addressing the listener) \\
\cline { 2 - 5 } & $3 \mathrm{Sg}$ & 17 & 3 & 7 \\
\cline { 2 - 5 } & $1 \mathrm{PI}$ & 1 & - & 1 \\
\cline { 2 - 5 } & $2 \mathrm{PI}$ & - & - & - \\
\cline { 2 - 5 } & $3 \mathrm{PI}$ & 1 & - & - \\
\hline Time & & 8 & 4 & 2 \\
\hline
\end{tabular}

The narrator uses the primary role deixis (part of Estonian personal deixis, expressed by $\mathrm{Sg} 1$ and $\mathrm{Sg} 2$ ) and the demonstrative deixis most in all narratives. Compared with the Estonian narrative, the narrator uses 36\% more of demonstrative deixis in the Võru narrative (32 and 46 demonstrative deictics in the Estonian and in the Võru narrative respectively). In both the Estonian and Võru narratives, the narrator uses the demonstrative deictic see/too 'this'/'that' most (18 and 40 times in the Estonian and Võru narrative respectively). The demonstrative deictic seal 'there' is used more in the Estonian narrative (10 and 4 times in the Estonian and Vorru 
narrative respectively). Different forms of the pronoun tää 'this' are used in the Finnish narrative. The pronoun tuo 'that' is used once.

The narrator uses deictics approximately 50\% more in the Estonian narrative than in the Vorru narrative (six and four times respectively). In both the Estonian and the Võru narrative, the most frequent time deictic is siis 'then' marking the succession of events. The narrator uses deictics just twice in the Finnish narrative nüt 'now' and sis 'then' (the pronunciation by the respondent).

In all three narratives, the narrator uses the primary role deixis the most $(48,51$ and 25 times in Estonian, the Võru dialect and Finnish respectively). Compared with the other narratives, the narrator uses much Sg3 deixis in the Estonian narrative. It seems that in the Vorru narrative $\mathrm{Sg} 3$ deixis is substituted with the demonstrative pronoun tuu 'that' as $\mathrm{Sg} 3$ deictics are used only three times. Sg3 deictics appear seven times in the Finnish narrative. In the Estonian narrative, the narrator addresses the listener using Sg2 and uses both an impersonal and a passive verb once. In the Võru narrative she uses generic 'you' three times.

Pajusalu (1999) mentions that applying the demonstrative deictic see 'this' to a person could have a derogatory effect and in this way, the narrator might distance herself and the listener from the person she is speaking about (demonstrative deixis takes the role of affective deixis). Potts and Schwarts (2010) note about English this that the narrator might wish to engage the listener emotionally and the referent of 'this' is often judged by the narrator. In the Vorru narrative, the use of the demonstrative deictic tuu 'that' in the way Pajusalu described can be discerned:

(1) aga mul tuu sõbranna tuu X (.) tuu brigadiri tütar (.) tuule tuu plaan es meeldü

'but my that girlfriend, that X (.) that daughter of the foreman (.) that (friend) didn't like that plan'

According to Potts and Schwarts, the narrator can be seen as trying to create an emotional connection in the Estonian narrative:

(2) lõpuks ma hüppasin selga sõitsin selle lehmaga seal mingi kümme minutit [---] ja ta tahtis mind selle lehma seljast maha hirmutada

'finally, I got up to rode on this cow for some ten minutes [---] and she wanted to scare me off this cow'

In the Võru narrative, the distancing tuu 'that' and in the Estonian narrative emotionally connecting see 'this' appear in the same thematic block. It is not possible to find any affective deixis in the Finnish narrative.

In all three narratives, the narrator uses the primary role deixis the most. The second most frequently used type of deixis is demonstrative deixis. The narrator favours demonstrative deictics see/too, tuu and tää 'this'/ 'that'. Although the event took place in the past, the narrator does not use many time deictics. In the Estonian narrative, she uses the time deictic siis 'then' the most. The narrator uses demonstrative deictics see 'this' in Estonian and too 'that' in the Võru dialect as affective deixis. 


\subsection{Emotional repertoire}

In the first thematic block of the Estonian narrative, mostly positive emotion words are used.

(3a) kihvt karjapäev 'a memorable day in the pasture'

(3b) hea lugu 'a good story'

(3c) suur lehmasõber 'a great cow fancier'

(3d) väga rahul 'very happy'

(3e) meeldima 'to like'

(3f) lemmikud 'favourites'

The Võru and Finnish narratives do not hold such emotions at all.

Parallels can be observed in the emotion vocabulary in all three narratives in the third thematic block.

(4a) kergem töö (Estonian) 'an easier job'

(4b) hää elo, ull töö (Võru) 'a good life, a crazy job’

(4c) tosi hüvä tüö paha tüö (Finnish) 'a very good job, a bad job'

After the third thematic block, the Estonian and Võru narrative concentrate on boredom, but the Finnish narrative tells about a big dream.

Later in the narrative, the Estonian narrative conveys irritation, jealousy and shouting.

(5a) ta oli ärritunud 'she was irritated'

(5b) ta ei vaadanud selle peale küll positiiuselt 'she did not have any positive feelings towards it'

(5c) teda hakkas see ärritama 'this situation irritated her'

(5d) ta oli ilmselgelt kade 'she was obviously jealous'

(5e) ta hakkas karjuma 'she started shouting'

(5f) ja karjub seal 'and she is shouting there'

The Võru narrative describes mainly dislike and fright in the same thematic blocks or the adjacent thematic blocks.

(6a) tuule tuu plaan es meeldü 'that (girl) didn't like that plan'

(6b) nakasi lehmä hirmutamas 'she started frightening the cow'

(6c) nakse plaksutama õkvalt tämä nïmoodi hirmutama'she started clapping in order to frighten'

(6d) hirmutas takka 'she scared [the cow] even more'

In the Finnish narrative, the narrator uses only words conveying positive emotions even when she wants to describe a negative emotion.

(7a) ma nii onnelik 'I'm so happy'

(7b) onnelinen ihminen 'a happy person'

(7c) hän es rakasta 'she doesn't like'

Then, in Estonian the narrator describes falling into manure as simply an unpleasant event. 
(8) see ei olnud kõige parem, see oli ebameeldiv 'it wasn't the best thing, it was unpleasant'

In the Võru dialect she uses much more vivid words for describing the same event.

(9) ullumaja tuu tuu tunne ja tuu hais 'it was bedlam there that that feeling and that smell'

In the Finnish narrative, the narrator only gives a summary of the event and does not use emotion words at all.

At the end of the narrative, the narrator describes her anger and her friend's gloating in Estonian:

(10) ja ma olin väga vihane X peale aga X-loliväga hea tunne väga hea meel 'and I was very angry at X but X had a very good feeling very happy'

In the Võru dialect she describes her guilt and her friend's gloating:

(11) ja X-l oll hää miil, ja süüdi jäi iks ma 'and X was happy, and I was the guilty one [in letting the cows go home earlier]'

In the Finnish narrative, the narrator describes also the friend's gloating, but positive emotions dominate:

(12) X-l nii hüvä miel, hän naara viela, hänen naara viela ' $\mathrm{X}$ [is] so happy, she is laughing, she is laughing'

The only negative emotion word vihaista 'angry' in the Finnish narrative is at the end:

(13) kaiki oli viela vihaista 'all were angry [at us]'

The choice of emotion words in the Estonian and Võru narrative is slightly different (Estonian 'irritate' vs. Võru 'scare'; Estonian 'I was angry' vs. Võru 'I was the guilty one'). In the Finnish narrative, the narrator uses positive emotion words even when she wants to express negative emotions. As in tense formation in Finnish, where the influence of the Võru dialect was noticeable, the Finnish narrative presents many cases of quasi-Finnish creations, similar to the situation described in Verschik's study (2012) on receptive multilingualism in communication between Estonian frontline employees and Finnish customers.

\section{Interpretation}

The narrator's perception of time and her place in it seems to be different in the Võru and Estonian narratives. In the Võru dialect, she speaks more slowly, the average utterance is shorter than that of the Estonian and there are more pauses between the utterances. On the one hand, time adverbials give a time frame to the narrative; on the other hand, they create an impression that time runs somehow slower for the narrator. The narrator uses time deictics approximately 50\% less than in the Estonian narrative, which also gives an impression of time running slowly. Many present tense forms are used. This makes the narrative emphatic and places the narrator in the middle of the events. 
She speaks more rapidly in Estonian, her average utterance is longer than that of the Võru utterance and there are few pauses between the utterances. Time adverbials show that the narrative lacks a clear time frame. In Estonian, the adverb siis 'then' is used as a time deictic to signal the quick succession of events. The narrator uses many past tense forms and so places herself outside the events, becoming a neutral observer. Compared with the Võru narrative, the Estonian narrative is less structured and the variety of tenses used is small.

The average length of the Finnish narrative is comparable with that of the Võru narrative, but here the pauses demonstrate the narrator looking for appropriate words. Also the use of tenses does not show whether the narrative is emphatic. The narrative is divided into three clear-cut parts by the use of tenses: the introduction is in the past, the description of the events in the present and the conclusion again in the past. The historical present of the Võru narrative is absent from the Finnish narrative and the present is used illogically from time to time. It can be assumed that the narrator finds it easier to form present tenses than past tenses. In the whole Finnish narrative, the narrator uses only two time deictics nüt 'now' and sis 'then'. Of the three narratives, the Finnish narrative seems to be the most rigid.

All narratives are rather 'self-centred' as the narrative is about a personal experience. However, in the narratives the narrator shifts focalisation away from herself using different means. In the Estonian narrative, she uses $\mathrm{Sg} 3$ deixis, the passive voice, impersonal verbs, the direct speech and addressing the listener directly. In the Võru narrative, she uses the affective deictic tuu 'that', the direct speech, generative 'you' and the secondary role deixis. Shifting the focalisation in the Finnish narrative is not clearly noticeable although the narrator uses the Sg3 deictic hän 'she'.

Both in the Võru and Estonian narratives, demonstrative deixis is used as affective deixis in the same thematic blocks. In the Estonian narrative, the narrator uses the affective deictic see 'this' (see Potts and Schwarts 2010) to engage the listener emotionally. In the same block in the Võru narrative, the narrator uses the affective deictic tuu 'that' (Pajusalu 1999) to distance herself and the listener from the person referred to. By doing so, she also judges the person. In the Finnish narrative, demonstrative deixis (mainly different forms of the pronoun tää 'this') is not used as affective deixis.

Emotion words used in the three narratives presumably demonstrate the differences in the emotional repertoires that are available to the narrator in her different languages. In the Estonian narrative the narrator expresses her positive feelings towards her work. This positive emotion is absent from the other narratives. The common denominator of the Estonian and Võru narratives is the friend's gloating, but in Estonian the narrator expresses her anger towards her friend, whereas in the Võru narrative the narrator communicates the injustice she feels.

The narrator describes falling into manure neutrally in Estonian, but with emotion in the Võru dialect.

In the Finnish narrative, the narrator expresses both positive and negative emotions by positive emotion words. The only negative emotion word in the Finnish narrative is 'to get angry'. This can be explained by the fact that as the narrator uses Finnish mainly in oral professional communication (service industries), she does not have the vocabulary to express negative emotions. 
As the Võru narrative is the longest, it can be presumed to be most detailed. The narrative has eight unique details missing from the other narratives. These details are mostly connected with village life, the cattle and specific names and numbers. The Estonian narrative has two unique details connected with positive emotions towards work. There is also a detailed description of the cow in Estonian that is absent from other narratives. The Finnish narrative has three unique details that describe people as the narrative has two new thematic blocks absent from the other narratives.

It is interesting how the narrator describes the other main character - the friend, "this daughter of a foreman". In the Võru dialect, the friend appears at very the beginning of the narrative. In Estonian, the friend is presented only in the second half of the narrative before the thematic block where the friend is one of the central characters. In the Võru narrative, the narrator stresses three times that the friend is a foreman's daughter; in the Estonian narrative she mentions this only once. So it can be said that in the Estonian narrative the main characters are the narrator and the cow, and the friend is just a secondary character whose task is to complicate the events. The Võru narrative, however, has three characters - the narrator, the cow and the friend. Stressing that the friend is a foreman's daughter in the Võru narrative could refer to the hierarchy of kolkhozy and sovkhozy of the Soviet era where everyone knew their place as department heads, head accountants, foremen, milkmaids etc. The narrator does not stress the hierarchy in Estonian and expresses her pride in being a milkmaid's daughter. However, the word choice in the Vorru narrative suggests that the narrator is ashamed rather than proud of being a milkmaid's daughter.

The Finnish narrative does not stress the sovkhoz hierarchy either. Most likely, it is because the narrator lacks the appropriate vocabulary. Obviously, it was difficult for the narrator to tell this story in Finnish which lacks the thematic vocabulary. For example, in Finnish the foreman's daughter is described as 'the big boss's daughter'.

\section{Discussion}

The language biography shows that the respondent learned Estonian and the Võru dialect simultaneously. Therefore, it is difficult to determine whether the respondent's L1 is Estonian or the Võru dialect. The respondent used the Võru dialect in informal contexts (with the family and older people) and Estonian in formal contexts (at school). The situation has not changed: the respondent uses the Vorru dialect within the family and Estonian in the professional context. Therefore, it can be said that the present case study somewhat supports the hypotheses by ErvinTripp (1964), Bond and Lai (1986) and Javier et al. (1993). As in the research by Ervin-Tripp, the Estonian narrative seems to be more abstract and the themes are different from those of the Võru narrative. Estonian might sound more abstract as the respondent used it mostly in the education system, which deals with more abstract topics (cf. Bond, Lai 1986). The Võru narrative is the longest of the three narratives, presenting details that were missing in the other two narratives. This agrees to some extent with the conclusion by Javier et al. (1993), who found that the L2 narrative is rather a summary of the L1 narrative. However, the present case 
study does not allow us to claim that any of the three narratives is a mere summary of the events. In the research by Javier et al., the impression of a summary could be because of too short an interval between the two sessions. During the second session the respondents were probably able to remember the exact content of the narrative and thus might have preferred to summarise their previous narrative. The researchers also allowed the respondents to choose the language of the first session. It is likely that the respondents chose their L1 or dominant language for the first session and were therefore able to narrate in a more lively and detailed way. In the present case study, it was impossible to determine whether Estonian or the Vorru dialect is the narrator's L1. The case study therefore demonstrates that L1 being the dominant language is only one possible multilingual situation.

Also, it should be taken into account at which level the narrative is recycled and whether it has been told before. Some respondents may not consider the second session as important since they have already told their story. Some respondents regard the second session as a good opportunity to elaborate on the previously told narrative. It is rather likely that in the present case study the multilingual narrative is a deeply recycled one, which is the reason why all three narratives have a rather similar structure.

Like in Koven (1998), this respondent was asked her subjective opinion about whether she feels differently when speaking her other languages. The respondent denied it. The linguistic, thematic and narratological analysis could allow the finding that the respondent has different selves for her different languages. However, the case study is too limited to give enough information to claim this. I believe that the respondent could take on different roles in her different languages, or she could develop different narratological identities. Studying the development of narratological identities in different languages and the adequate analysis requires longer narratives, though. This, however, is not within the scope of the present study.

Like in Pavelnko (2002), Pavlenko and Driagina (2007), Panayiotou (2004), and Marian and Kaushanskaya (2008), it appeared that the respondent of the present case study has indeed different emotional repertoires in her different languages. As the respondent does not use Finnish for narrating or higher level monologues but only to communicate professionally, presumably she does not have a wide emotional repertoire in Finnish. In the Finnish narrative, she uses positive emotion words for expressing negative emotions which could show that she has not found any need for negative emotion words in her professional communication and therefore has not acquired them. This confirms the research of Pavlenko (2002) and Pavlenko and Driagina (2007). For the respondent, Estonian and the Võru dialect seem to activate different socio-cultural frameworks as well. Although the structures of the Estonian and Võru narrative are identical, the themes of these narratives are different. In Estonian, the respondent distances herself from the events, expresses pride in her work ethics and shows herself as independent in every way. In the Võru dialect, however, the narrator describes the hierarchy, expresses shame over her place in this hierarchy and the feeling of injustice because of the events. There are no clear themes in the Finnish narrative probably because of the respondent's insufficient language skills. 


\section{Conclusion}

The multilingual narratives of the present case study are not very different structurally. There are differences in thematic stresses, however. The structure of the Finnish narrative has been changed by adding and losing thematic blocks. The Estonian and Võru narratives are identical by structure but different by themes. The Finnish narrative does not have a distinctive thematic stress.

The Võru dialect seems to have a greater emotional intensity for the respondent, although she learned Estonian and the Võru dialect simultaneously and the Võru dialect cannot be considered as her L1. However, the Võru narrative is the longest of the three narratives and contains the highest number of unique details. The respondent also uses affective deixis in the Võru dialect. Finnish seems to be the most emotionally distant of the three languages for the respondent.

The claim that the respondent has different identities in her different languages seems arbitrary at the moment, although the thematic differences in the Estonian and Võru narratives could allow us to infer that. It should be determined whether, in the case of the Estonian and Võru narratives, the respondent could have deployed different roles or whether the reasons for thematic differences in the narratives could be because of the separate narratological identities connected to different languages.

The emotional repertoires used in the Estonian and Võru narratives are rather similar to each other. The differences in the emotional repertoires, and also in the themes, may arise most likely from the fact that the Estonian and the Võru dialects trigger different socio-cultural frameworks in the respondent. Estonian, the language the respondent uses in education and professionally, helps her to distance herself from the events. Using the Vorru dialect, the respondent describes the Soviet hierarchical sovkhoz environment. However, the Finnish emotional repertoire of the respondent is rather one-sided because of the limited language means.

The present case study is part of a more extensive study that includes narratives by ten respondents and is conducted in a similar way to the present case study.

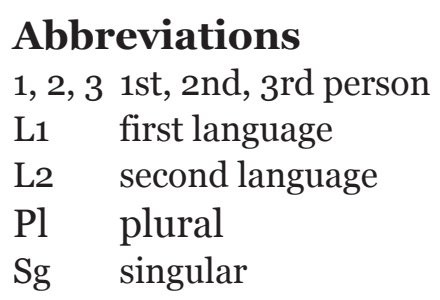

\section{References}

Altarriba, Jeanette 2003. Does carino equal "liking"?: A theoretical approach to conceptual nonequivalence between languages. - International Journal of Bilingualism, 7 (3), 305-322. http://dx.doi.org/10.1177/13670069030070030501

Anooshian, Linda; Hertel, Paula 1994. Emotionality in free recall: Language specificity in bilingual memory. - Cognition \& Emotion, 8 (6), 503-514. http://dx.doi. org/10.1080/02699939408408956

Bond, Michael; Lai, Tat Ming 1986. Embarrassment and code-switching into a second language. - Journal of Social Psychology, 126 (2), 179-186. 
Dewaele, Jean-Marc; Pavlenko, Aneta 2001-2003. Web questionnaire "Bilingualism and "Emotions". University of London.

Dewaele, Jean-Marc 2004. The emotional force of swearwords and taboo words in the speech of multilinguals. - Journal of Multilingual and Multicultural Development, 25 (2-3), 204-222. http://dx.doi.org/10.1080/01434630408666529

Ehala, Martin 2004. Keelehoid ja mitmikidentiteet. - Karl Pajusalu, Jan Rahman (Toim.). Kiil ja hindätiidmine / Keel ja identiteet. Võro Instituudi Toimõndusõq 16. Võru: Võro Instituut.

Ervin-Tripp, Susan 1964. Language and TAT content in bilinguals. - Journal of Abnormal and Social Psychology, 68, 500-507. http://dx.doi.org/10.1037/ho044803

Fludernik, Monika 2003. Chronology, time, tense and experentality in narrative. - Language and Literature, 12 (2), 117-134. http://dx.doi.org/10.1177/0963947003012002295

Javier, Rafael; Barroso, Felix; Muñoz, Michele 1993. Autobiographical memory in bilinguals. Journal of Psycholinguistic Research, 22 (3), 319-338. http://dx.doi.org/10.1007/ BF01068015

Koven, Michèle 1998. Two languages in the self / the self in two languages: French-Portuguese bilinguals' verbal enactments and experiences of self in narrative discourse. - Ethos, 26 (4), 410-455. http://dx.doi.org/10.1525/eth.1998.26.4.410

Lindström, Liina; Kalmus, Mervi; Klaus, Anneliis; Bakhoff, Liisi; Pajusalu, Karl 2009. Ainususe 1. isikule viitamine eesti murretes. - Emakeele Seltsi aastaraamat, 54 (2008), 159-185.

Marian, Viorica; Kaushanskaya, Margarita 2004. Self-construal and emotion in bicultural bilinguals. - Journal of Memory and Language, 51 (2), 190-201. http://dx.doi. org/10.1016/i.jml.2004.04.003

Marian, Viorica; Kaushanskaya, Margarita 2008. Words, feelings, and bilingualism: Crosslinguistic differences in emotionality of autobiographical memories. - The Mental Lexicon 3 (1), 72-90. http://dx.doi.org/10.1075/ml.3.1.06mar

Pajusalu, Renate 1999. Deiktikud eesti keeles. http://www.folklore.ee/seminar/deiktikud (22.09.2012).

Panayiotou, Alexia 2004. Switching codes, switching code: Bilinguals' emotional responses in English and Greek. - Journal of Multilingual and Multicultural Development, 25 (2-3), 124-139. http://dx.doi.org/10.1080/01434630408666525

Pavlenko, Aneta 2002. Bilingualism and emotions. - Multilingua, 21 (1), 45-78. http:// dx.doi.org/10.1515/mult.2002.004

Pavlenko, Aneta 2006. Bilingual minds: emotional experience, expression, and representation. - Aneta Pavlenko (Ed.). Bilingual Selves. Clevedon: Multilingual Matters, 1-33.

Pavlenko, Aneta 2007. Autobiographic narratives as data in applied linguistics. - Applied Linguistics, 28 (2), 163-188. http://dx.doi.org/10.1093/applin/ammoo8

Pavlenko, Aneta 2008. Narrative analysis. - L. Wei, G. M. Moyer (Eds.). The Blackwells Guide to Research Methods in Bilingualism and Multilingualism. Blackwell Publishing Ltd, 311-325.

Pavlenko, Aneta; Dewaele, Jean-Mark 2002. Emotion vocabulary in interlanguage. - Language Learning, 52 (2), 263-322. http://dx.doi.org/10.1111/0023-8333.00185

Pavlenko, Aneta; Driagina, Viktoria 2007. Russian emotion vocabulary in American learners' narratives. - The Modern Language Journal, 91 (2), 213-234. http://dx.doi. org/10.1111/j.1540-4781.2007.00541.X

Piller, Ingrid 2002. Passing for a native speaker: Identity and success in second language learning. - Journal of Sociolinguistics, 6 (2), 179-208. http://dx.doi. org/10.1111/j.1540-4781.2007.00541.X

Potts, Christopher; Schwarts, Florian 2010. Affective 'this'. - Linguistic Issues in Language Technology, 3, 1-30. 
Schiffrin, Deborah 1981. Tense variation in narrative. - Language 57 (1), 45-62. http:// dx.doi.org/10.2307/414286

Verschik, Anna 2010. Keeleliste elulugude uurimisvõimalusi: Dagmar Normeti mitmekeelne lapsepõlv Eestis. - Methis. Studia humaniora Estonica, 5/6, 175-188.

Verschik, Anna 2012. Practicing receptive multilingualism: Estonian-Finnish communication in Tallinn. - International Journal of Bilingualism, 16 (3), 265-286. http://dx.doi. org/10.1177/1367006911426465

Wierzbicka, Anna 2004. Bilingual Lives, Bilingual Experience. - Journal Of Multilingual and Multicultural Development, 25 (2-3), 94-104. http://dx.doi. org/10.1080/01434630408666523

Wolfson, Nessa 1979. The conversational historical present alternation. - Language 55 (1), 168-182. http://dx.doi.org/10.2307/412521

Liina Tammekänd (Tartu Ülikool) on erialalt tõlkija, uurimisvaldkonnaks on mitmekeelne narratiiv. liina.tammekand@ut.ee 


\section{LÕUNA-EESTLASE MITMEKEELSUS - EESTI, VÕRU JA SOOME NARRATIIVIDE VÕRDLUS}

\section{Liina Tammekänd}

Tartu Ülikool

Artikkel käsitleb juhtumiuuringut, mille aluseks on 31-aastase Võrumaalt pärit naise esitatud kolm samateemalist isikliku kogemuse narratiivi võru murdekeeles, eesti ja soome keeles ning tema keeleelulugu.

Autor salvestas, transkribeeris ja analüüsis narratiive pidades silmas nelja uurimisküsimust: kas narratiivid erinevad üksteisest struktuuriliselt ja temaatiliselt, kas keelejuhi esimesena omandatud keel on talle emotsionaalselt lähemal, kas keelejuht demonstreerib erinevates keeltes osaidentiteedi erinevaid tahke ning kas keelejuht kasutab erinevates keeltes erinevaid emotsioonirepertuaare.

Eesti ja võru narratiivid on struktuurilt identsed, kuid temaatiliselt erinevad. Soome narratiivi struktuur sarnaneb üldiselt teiste narratiivide struktuuriga, kuid temaatika nii selgelt välja ei joonistu. Temaatika ning valitud emotsioonisõnade tõttu tundub, et võru murdekeel on keelejuhile võrreldes teiste keeltega emotsionaalselt lähemal. Lingvistiline ja temaatiline analüüs ei luba hetkel oletada, et keelejuht demonstreerib erinevates keeltes osaidentiteedi eri tahke. Erinevused eesti ja võru emotsioonisõnavarades tulenevad peamiselt narratiivide erinevast temaatikast. Soome narratiivi ebaselge temaatika ning ühekülgne emotsioonisõnavara tulenevad ilmselt sellest, et keelejuht on soome keele omandanud töökontekstis.

Võtmesõnad: mitmekeelsus, suuline narratiiv, emotsioonisõnavara, eesti keel, võru murre, soome keel 